\title{
Microstructures and Electrochemical Studies of Flux-Cored Arc and Flux-Copper Back Welded EH36 Steel
}

\author{
Kai Wang ${ }^{1,2, *}$, Qinghua $\mathrm{Lu}^{1}$, Yaoyong $\mathrm{Yi}^{2}$, Ben Niü ${ }^{2}$, Jianglong $\mathrm{Yi}^{2}$, Zexin Jiang ${ }^{3}$, Jinjun $\mathrm{Ma}^{3}$ \\ ${ }^{1}$ Foshan University, Foshan, Guangdong, 528000, China \\ ${ }^{2}$ Guangdong Welding Institute (China-Ukraine E. O. Paton Institute of Welding), Guangzhou, \\ Guangdong, 510651, China \\ ${ }^{3}$ Guangzhou Shipyard International Co., Ltd, Guangzhou Guangdong, 510380, China \\ *E-mail: wk927@qq.com
}

doi: $10.20964 / 2018.03 .24$

Received: 19 February 2017 / Accepted: 25 December 2017 / Published: 5 February 2018

\begin{abstract}
EH36 high strength steel plates were welded using flux-cored arc welding (FCAW) and flux copper backing (FCB) one-side submerged-arc welding (SAW) technology. The microstructure, microhardness distribution, and electrochemical behavior of the joints were studied. Because of the interaction of the thermal circle effect by the multi-layer and multi-pass welding modes of the FCAW, an asymmetric microhardness distribution resulted along the horizontal cross section lines caused by the softening phenomena. The high welding heat input FCB welding technology resulted in welding the joints with uniform microstructure and a symmetrical microhardness distribution along the horizontal cross section lines as well as a relatively stronger electrochemical behavior.
\end{abstract}

Keywords: High strength steel; FCAW; FCB; Microstructure; Electrochemical Impedance behavior

\section{FULL TEXT}

(C) 2018 The Authors. Published by ESG (www.electrochemsci.org). This article is an open access article distributed under the terms and conditions of the Creative Commons Attribution license (http://creativecommons.org/licenses/by/4.0/). 